\title{
Plasma concentration of progesterone and $17 \beta$-estradiol of black-rumped agouti (Dasyprocta prymnolopha) during the estrous cycle
}

\author{
Diva Anelie Guimarães ${ }^{1}$, Rosemar Luz Ramos ${ }^{1}$, Otávio Mitio Ohashi ${ }^{1}$, Gary Wayne Garcia ${ }^{2}$ \& \\ William Gomes Vale ${ }^{3}$ \\ 1. Laboratory of Animal Reproduction, Institute of Biological Sciences, Federal University of Pará, Rua Augusto Corrêa, \\ 01, Guamá, CEP 66075-110, Belém, Pará, Brazil; diva@ufpa.br, roseluz@ufpa.br, ohashi@ufpa.br \\ 2. The University of the West Indies, St. Augustine Campus, Faculty of Science and Agriculture Department of Food \\ Production, The Open Tropical Forage-Animal Production Laboratory, St. Augustine, Trinidad and Tobago, West \\ Indies; garygwg1@gmail.com \\ 3. West Federal University of Pará, Institute for Animal Health and Production, Department of Bioscience and Forest, \\ Campus Universitario do Tapajós, Av. Vera Paz s/n, Bairro Salé, CEP 68040-070, Santarém, Pará, Brazil; \\ wmvale@hotmail.com
}

Received 15-II-2010. Corrected 22-VIII-2010. Accepted 20-IX-2010.

\begin{abstract}
Plasma concentration of progesterone and 17 $\beta$-estradiol of black-rumped agouti (Dasyprocta prymnolopha) during the estrous cycle. The agouti is a game animal that have been raised in captivity for conservation and sustainability purposes. However, the management of wild animals in an intensive breeding system requires an assertive knowledge of its reproductive parameters, one of the most important features for production improvement. Besides, little information is available regarding changes in reproductive hormone profiles in agouti. The objective of this study was to evaluate the hormonal profile of progesterone and $17 \beta$-estradiol during the estrous cycle of the agouti (Dasyprocta prymnolopha). The hormones were analyzed by radioimmunoassay. Blood samples were collected without sedation twice a week. The concentrations of progesterone were as follows: proestrus $0.78 \pm 0.39 \mathrm{ng} / \mathrm{ml}$, estrus $2.83 \pm 2.34 \mathrm{ng} / \mathrm{ml}$, metestrus $1.49 \pm 1.24 \mathrm{ng} / \mathrm{ml}$, diestrus $3.71 \pm 1.48 \mathrm{ng} / \mathrm{ml}$. In the estrous phase, an increase in the progesterone level was observed during a period of $24 \mathrm{~h}$. The average 17 $\beta$-estradiol levels were as follows: proestrus $2030.98 \pm 961.00 \mathrm{pg} / \mathrm{ml}$, estrus $1910.56 \pm 650.54 \mathrm{pg} / \mathrm{ml}$, metestrus 1 $724.83 \pm 767.28 \mathrm{pg} / \mathrm{ml}$, diestrus $1939.94 \pm 725.29 \mathrm{pg} / \mathrm{ml}$. The current results suggest that the progesterone plasma concentration during the estrous cycle in the agouti has a similar increasing, stabilizing and decreasing pattern, as in domestic mammals. Agoutis have two phases of follicular development, as two periods of $17 \beta$-estradiol peaks were observed, the first one in the metestrus and the second during the proestrus. Spontaneous ovulation seems to occur after the progesterone peak, possibly indicating that this hormone is associated with the ovulatory process. A more detailed investigation is needed for better understanding of how progesterone influences ovulation. Studies on the involvement of progesterone in follicular rupture can be carried out, using steroid biosynthesis inhibitors and observing the effect of this hormone on ovarian activity of proteolytic enzymes in the follicular wall. Rev. Biol. Trop. 59 (1): 29-35. Epub 2011 March 01.
\end{abstract}

Key words: Dasyprocta prymnolopha, reproduction, estrous cycle, progesterone, 17ß-estradiol, Brazilian Amazon.

Successful wildlife management is directly related to reproduction programs, which require hormone monitoring to determine the estrous cycle, onset of puberty, duration of sexual receptivity, effect of season, pregnancy diagnosis, birth timing and physical fitness (Wildt \& Wemmer 1999). Reproductive hormones, which can be measured in urine, feces, saliva and blood, are fundamental to regulate reproductive functions and may be used to improve reproductive management.

The reproductive endocrinology of most wild mammals is largely unknown and the endocrine physiology of Amazon animals is even less 
known. Understanding how the animals reproduce may contribute to improve reproduction biotechnologies, including artificial insemination, in vitro fertilization, embryo transfer and cryopreservation (Fickel et al. 2007). These are very important tools for in situ and ex situ wildlife conservation and animal production.

Native of Central and South America animals, such as the rodents, paca Agouti paca, capybara Hydrochoerus hydrochaeris and agouti Dasyprocta sp., have potential for increase microlivestock production, since they represent the main protein sources for local populations (Bonaudo et al. 2005, National Research Council 1991).

Considerable effort has improved the knowledge of the reproductive physiology of the agouti (Guimarães 1993, 2000, Guimarães et al. 2009, Heap et al. 1981, Miglino et al. 2002, 2004, 2008, Rodrigues et al. 2006, Weir 1971, 1974); however, this species still requires further study.

The agouti is one of the most consumed game animals in the Brazilian Amazon (Bonaudo et al. 2005). An intensive breeding system of this animal will contribute to its conservation and can provide an alternative sustainable production.

Little information is available regarding changes in progesterone and estradiol levels during estrous cycle in agouti, compared to that in other hystricomorphs rodents (Adjanohoun 1992, Barta \& Jakubicka 1991, Croix \& Franchimont 1975, Faulkes et al. 1990, Montes \& Baz 2006, Rowlands et al. 1970, Tam 1973, Van Aarde 1985). It is expected that the physiological parameters of progesterone and estrogen during the estrous cycle in agouti are similar to other hystricomorphs.

The aim of this work was to study the estrous cycle of the agouti (Dasyprocta prymnolopha) by analysis of reproductive hormones, progesterone and $17 \beta$-estradiol.

\section{MATERIAL AND METHODS}

This research was conducted at the wildlife paddock $\left(4 \mathrm{~m}^{2}\right)$ of the Animal Reproduction
Laboratory of the Federal University of Pará, Belém, Brazil. Agoutis (Dasyprocta prymnolopha) were kept under natural lighting conditions. The paddocks annual average temperature was $28^{\circ} \mathrm{C}$. Daily food supply was composed of corn bran (Zea mays), soy (Glycine hispida), pumpkin (Curcibita pepo), cassava (Manihot utilissima) and mineral salt; a nutritional complement (Potenay- Fort Dodge, Brazil) was provided periodically. All animals were born in captivity and belonged to F3 and F4 generations. The average weight of the experimental animals was $1.95 \pm 0.31 \mathrm{~kg}$.

The animals were divided into two groups, young and adult females. To compare the level of progesterone of nulliparous and pluriparous females and also to clarify whether ovulation occurs spontaneously or is copulation-induced, 18 females and 7 males were selected. The experimental groups were as follows:

Young females (9 months old): four groups of two nulliparous females and one vasectomized male.

Adult females (3 to 5 years old): three groups of two pluriparous females and one vasectomized male, and two groups of two pluriparous females kept isolated without a male.

Blood samples were collected without sedation twice a week $(72 \mathrm{~h}$ and $96 \mathrm{~h}$ intervals) or in shorter periods ( $6 \mathrm{~h}$ to $48 \mathrm{~h}$ ) next to the estrus by saphenous venipuncture. A $1 \mathrm{ml}$ syringe containing sodium heparin (Liquemine - Roche, Brazil) with a $261 \frac{1}{2}$ gauge needle (Baas et al. 1976) was used.

After collection, the blood was put in polypropylene tubes and immediately centrifuged at $1000 \mathrm{rpm}$ for $10 \mathrm{~min}$. The plasma was stored at $-20^{\circ} \mathrm{C}$ until assaying. Progesterone concentrations in plasma were determined for all females and $17 \beta$-estradiol was measured in five of the adult coupled females.

The hormone levels were measured by radioimmunoassay $\mathrm{I}^{125}$ in the solid phase (Diagnostic Products Corporation, USA, for dosage of progesterone; Immunotech, France, for dosage of $17 \beta$ estradiol). The assay quality control samples containing high and low hormone concentrations were included in the beginning 
and at the end of each assay. Intra-assay and inter-assay coefficient of variations were $11 \%$ and $10 \%$, respectively. The progesterone assay specificity was $100 \%$ (17-hydroxyprogesterone $0.3 \%, 20 \alpha$-dihydroprogesterone $2.0 \%$ ) and sensitivity was $0.02 \mathrm{ng} / \mathrm{ml}$. The $17 \beta$ estradiol assay specificity was $100 \%$ (estrone $1.3 \%$ and estriol $0.65 \%$ ) and sensitivity was $3 \mathrm{pg} / \mathrm{ml}$.

Colpocytology was performed to confirm the phase of the cycle and was applied according to Guimarães (1993), were as follows: proestrus-higher frequency of superficial and intermediate cells; estrus- higher number of superficial cells; metestrus-predominance of intermediate cells and leukocytes; diestrusprevalence of parabasal cells and the increase of basal cells.

Statistical analyses were performed using BioEstat version 5 (Ayres et al. 2008). The level of significance throughout the study was 0.05 $(\mathrm{p}<0.05)$. Statistical differences on hormonal levels for each phase of the cycle were estimated by analysis of variance (ANOVA). Values are expressed as the mean \pm standard deviation.

\section{RESULTS}

Twenty estrous cycles $(32.05 \pm 4.17$ days, 25 to 40 days) were verified in the adult females $(n=10)$ and no statistical difference ( $>0.05$ ) was observed in cycle length between mated and isolated females. The high levels of progesterone observed in isolated adult females after estrus confirmed spontaneous ovulation.

Comparing young and adult females, there was no statistical difference $(p>0.05)$ in the progesterone profile for each phase of the estrous cycle. However, the average progesterone concentration among the different phases of the estrous cycle phases was statistically significantly different $(\mathrm{p}<0.05)$ (Table 1$)$.

In the estrus, the initial progesterone concentration was low but it quickly increased in less than $24 \mathrm{~h}$ and seemed to remain constant for more than $31 \mathrm{~h}$. The progesterone concentration decreased in approximately 6h (Table 2 ). These data suggest that the estrus length is approximately $24 \mathrm{~h}$ and that ovulation happens after the progesterone concentration peak.

There was no statistical difference $(\mathrm{p}>0.05)$ in the $17 \beta$-estradiol levels between the cycle phases (Table 3). However, two peaks periods of $17 \beta$-estradiol were observed for all samples, the first in the metestrus and the second during the proestrus (Fig. 1), suggesting that there are two phases of follicular development.

The $17 \beta$-estradiol concentrations of one female, proestrus $77.26 \pm 20.71 \mathrm{pg} / \mathrm{ml}$ (62.62$91.91 \mathrm{pg} / \mathrm{ml})$, estrus $82.24 \pm 10.96 \mathrm{pg} / \mathrm{ml}$ (74.49$90 \mathrm{pg} / \mathrm{ml}$ ), metestrus $75.88 \mathrm{pg} / \mathrm{ml}$, diestrus $85.74 \pm 13.59 \mathrm{pg} / \mathrm{ml}(71.93-109.37 \mathrm{pg} / \mathrm{ml})$, were low when compared to the samples mentioned above (Fig. 2).

\section{DISCUSSION}

The current results suggest that plasma progesterone concentration during the estrous cycle in the agouti (D. prymnolopha) define an increasing, stabilizing and decreasing pattern similar to those of domestic mammals. We have observed that the progesterone values reported here were similar to many hystricomorph rodents, as reported previously for the

TABLE 1

Plasma level of progesterone ( $\mathrm{ng} / \mathrm{ml}$ ) during estrous cycle of 18 agoutis (D. prymnolopha)

\begin{tabular}{lccccc}
\multicolumn{1}{r}{ Phase } & Mean & Standard Deviation & Minimum & Maximum & Total samples \\
Proestrus & 0.78 & $\pm 0.39^{\mathrm{a}}$ & 0.22 & 2.04 & 90 \\
Estrus & 2.83 & $\pm 2.34^{\mathrm{b}}$ & 0.34 & 9.02 & 31 \\
Metestrus & 1.49 & $\pm 1.24^{\mathrm{c}}$ & 0.23 & 5.64 & 60 \\
Diestrus & 3.71 & $\pm 1.48^{\mathrm{d}}$ & 0.91 & 8.38 & 267
\end{tabular}

a,b,c,d Values with letters different in the same column are statistically significant $(\mathrm{p}<0.05)$. 
TABLE 2

Plasma level of progesterone ( $\mathrm{ng} / \mathrm{ml}$ ) during the estrus of adult agoutis (D. prymnolopha)

$\begin{array}{cccc}\mathrm{P} 4(\mathrm{ng} / \mathrm{ml})-1^{\text {st }} \text { harvest } & \mathrm{P} 4(\mathrm{ng} / \mathrm{ml})-2^{\text {nd }} \text { harvest } & \begin{array}{c}\text { Time (hours)- between } \\ 1^{\text {st }} \text { and } 2^{\text {nd }} \text { sample }\end{array} & \text { Hormone levels } \\ 1.72 & 3.05 & 6 & \text { Increase } \\ 1.71 & 13.39 & 24 & \text { Increase } \\ 2.02 & 3.21 & 24 & \text { Increase } \\ 4.38 & 5.41 & 24 & \text { Increase } \\ 8.46 & 7.94 & 31 & \text { Decrease } \\ 8.33 & 1.63 & 6 & \text { Decrease } \\ 8.01 & 1.04 & 24 & \text { Decrease } \\ 7.87 & 5.92 & 24 & \text { Decrease } \\ 6.23 & 1.42 & 6 & \text { Decrease } \\ 4.7 & 1.08 & 6 & \text { Decrease } \\ 3.99 & 2.06 & 24 & \text { Decrease }\end{array}$

TABLE 3

Plasma level of 17 $\square$ estradiol ( $\mathrm{pg} / \mathrm{ml}$ ) during estrous cycle of four agoutis (D. prymnolopha)

\begin{tabular}{lccccc}
\multicolumn{1}{c}{ Phase } & Mean & Standard Deviation & Minimum & Maximum & Total samples \\
Proestrus & 2030.98 & \pm 961.00 & 598.28 & 4137.53 & 17 \\
Estrus & 1910.56 & \pm 650.54 & 1162.91 & 2347.43 & 3 \\
Metestrus & 1724.83 & \pm 767.28 & 765.64 & 2956.58 & 9 \\
Diestrus & 1939.94 & \pm 725.29 & 357.6 & 2897.75 & 16
\end{tabular}
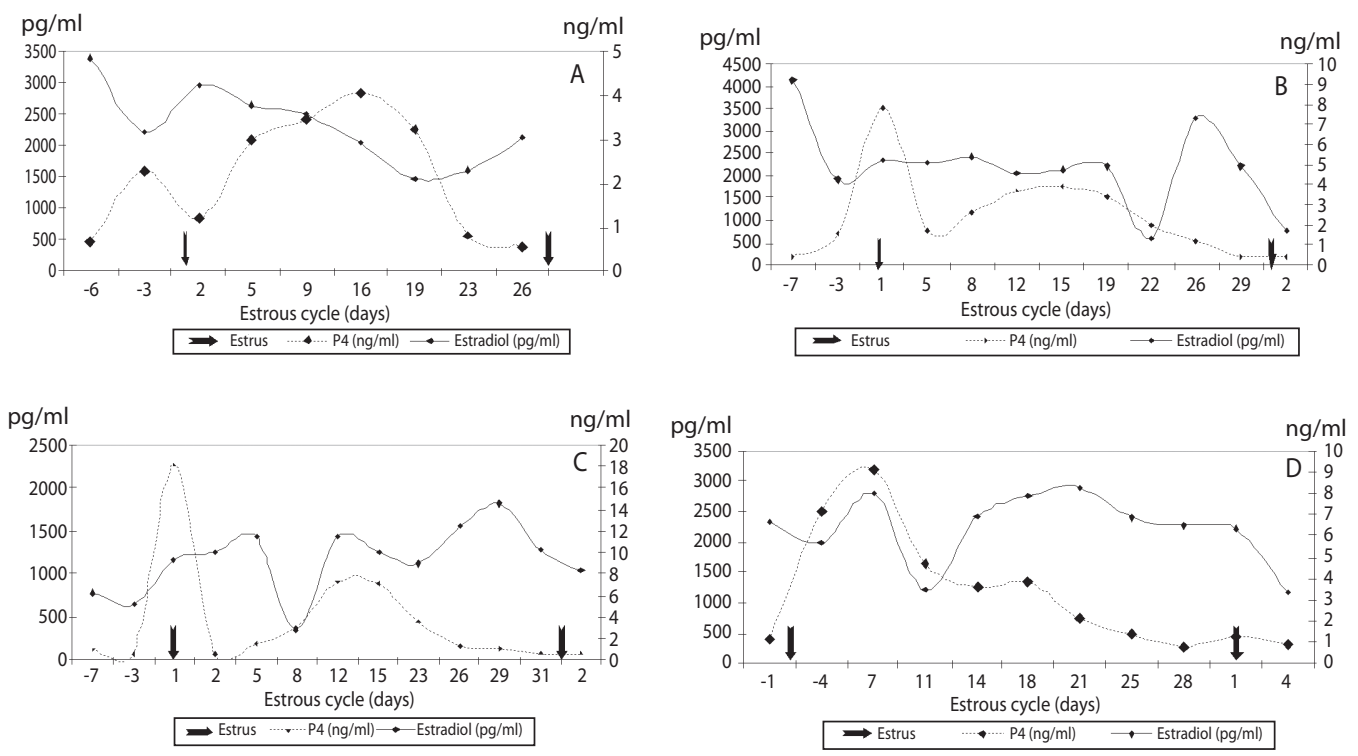

Fig. 1. Plasma estradiol-17 $\beta(\mathrm{pg} / \mathrm{ml})$ and progesterone $(\mathrm{ng} / \mathrm{ml})$ levels during the estrous cycle of four agouti females (A, B, C, D). 


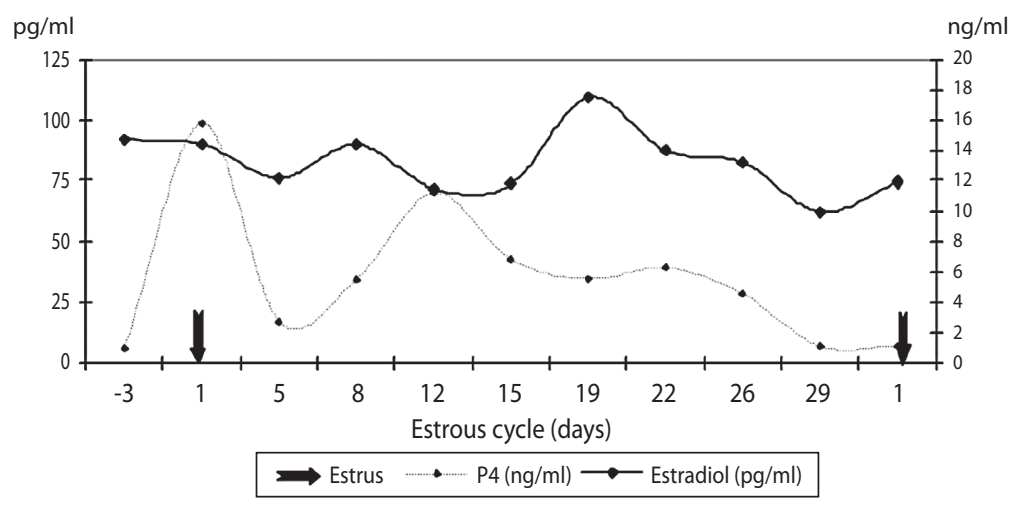

Fig. 2. Hormonal profile of estradiol-17 $\beta(\mathrm{pg} / \mathrm{ml})$ and progesterone $(\mathrm{ng} / \mathrm{ml})$ during the estrous cycle of one agouti $(D$. prymnolopha).

Cavia porcellus (Croix \& Franchimont 1975), Hystrix africaeaustralis (Van Aarde 1985) and Agouti paca (Montes \& Baz 2006). However, these values were lower than those observed in Myoprocta pratti (Rowlands et al. 1970), Galea musteloides (Tam 1973) and Hetreocephalus glaber (Faulkes et al. 1990). On the other hand, the data reported here were high, when compared to those observed in Myocastor coypus (Barta \& Jakubicka 1991) and Thryonomys swinderianus (Adjanohoun 1992). Presumptive the intra-species variation in progesterone levels is based on the function of the corpus luteum correlated with the metabolism of this steroid hormone.

Spontaneous ovulation occurred after the progesterone peak, possibly indicating that it is associated with the ovulation process. This peak of progesterone was similar to that described by Feder et al. (1968) and Croix \& Franchmont (1975) for the Cavia porcellus. In this species, the peak occurred a few hours before ovulation, which suggests the importance of this hormone in the ovulation process in some hystricomorph rodents. The pre-ovulatory follicles are probably responsible for a high production of progesterone during estrus. This may be one of the most important aspects of this study, however future research should be performed to confirm.

We found that the levels of $17 \beta$-estradiol during the estrous cycle showed an individual variation, as was also reported for the Cavia porcellus (Croix \& Franchimont 1975) and Hystrix africaeaustralis (Van Aarde 1985). In effect, we believe that the agoutis appear to have two phases of follicular development, since two periods of $17 \beta$-estradiol increase were found. This information will be useful when implementing reproductive biotechniques for conservation of this species.

In addition to these characteristics that have been outlined, reduced levels of $17 \beta$-estradiol were observed only in one female. Probably, the occurrence of low levels of this hormone may be correlated with slow follicular development. This has also been observed previously in species such as the Cavia porcellus (Croix \& Franchimont 1975), Hystrix africaeaustralis (Van Aarde 1985) and Agouti paca (Montes \& Baz 2006).

This study is the first attempt to interpret the physiological events during the estrous cycle of the agouti. The present results indicate that plasma steroids (progesterone and $17 \beta$-estradiol) monitoring provides an effective tool for obtaining information to improve reproductive programs of agouti conservation and production. Moreover, the data reported here also suggest the need for a more detailed investigation to better understand how progesterone influences the ovulatory mechanism in the agouti. 


\section{ACKNOWLEDGMENTS}

We thank the Federal University of Pará, their technicians for assistance in collecting materials for this research and the International Foundation for Science (Ref. B/2659-1) for supporting this project.

\section{RESUMEN}

El conocimiento de los procesos reproductivos de especies de importancia económica local son indispensables para apoyar su producción en cautiverio y garantizar su manejo sostenible. El objetivo del presente trabajo fue evaluar los niveles hormonales de progesterona y $17 \beta$-estradiol durante el ciclo estral en agutí (Dasyprocta prymnolopha). La recolección de sangre se realizó dos veces por semana, sin sedación. Las hormonas fueron analizadas por radioinmunoanálisis. Los niveles de progesterona fueron los siguientes: proestro $0.78 \pm 0.39 \mathrm{ng} / \mathrm{ml}$, estro $2.83 \pm 2.34 \mathrm{ng} / \mathrm{ml}$, metaestro $1.49 \pm 1.24 \mathrm{ng} / \mathrm{ml}$ y diestro $3.71 \pm 1.48 \mathrm{ng} / \mathrm{ml}$. En el estro se observó un aumento de los niveles de progesterona durante un periodo de $24 \mathrm{~h}$. Los niveles de $17 \beta$-estradiol fueron los siguientes: proestro 2 $030.98 \pm 961.00 \mathrm{pg} / \mathrm{ml}$, estro $1910.56 \pm 650.54 \mathrm{pg} / \mathrm{ml}$, metaesto $1724.83 \pm 767.28 \mathrm{pg} / \mathrm{ml}$ y diestro $1939.94 \pm 725.29 \mathrm{pg} /$ ml. Los resultados encontrados sugieren que los niveles plasmáticos de progesterona durante el ciclo estral en agutí siguen un patrón de aumento, estabilización y diminución, tal como en los mamíferos domésticos. Agutí tienen dos etapas de desarrollo folicular, puesto que se observaron dos altos valores de $17 \beta$-estradiol, el primero en el metaestro y el segundo durante el proestro. La ovulación espontánea ocurre posiblemente después del aumento de la progesterona, indicando que esta hormona posiblemente está asociada con el proceso ovulatorio. Es necesario desarrollar un estudio más detallado para mejorar la comprensión del papel de la progesterona en la ovulación. Algunos estudios de la participación de la progesterona en la ruptura folicular se pueden realizar utilizando inhibidores de la biosíntesis de esteroides y observar el efecto de esta hormona sobre la actividad de las enzimas proteolíticas en la pared folicular.

Palabras claves: Dasyprocta prymnolopha, reproducción, ciclo estral, progesterona, 17 $\beta$-estradiol, Amazonia brasileña.

\section{REFERENCES}

Adjanohoun, E. 1992. Le cycle sexuel et la reproduction de l'aulacode (Thryonomys swinderianus Temminck, 1827). Mammalia 56: 109-119.

Ayres M. Jr., D. Ayres \& A. Santos. 2008. Bioestat Versão 5.0. Sociedade Civil Mamirauá, MCT-CNPq, Brazil.
Baas, E.J., S. Potkay \& J. Bacher. 1976. The agouti (Dasyprocta sp.) in biomedical research and captivity. Lab. Anim. Sci. 26: 788-796.

Barta, M. \& I. Jakubička. 1991. Progesterone concentration in peripheral blood of nutria (Myocastor coypus) during the ontogenesis, sexual cycle, gravidity and lactation. Pol'nohospodárstvo 34: 371-389.

Bonaudo, T., Y. Le Pendu, J.F. Faure \& D. Quanz. 2005. The effects of deforestation on wildlife along the transamazon highway. Eur. J. Wildlife Res. 51: 199-206.

Croix, D. \& P. Franchimont. 1975. Changes in the serum levels of gonadotrophins progesterona and estradiol during the estrous cycle of the guinea pig. Neuroendocrinology 19: 1-11.

Faulkes, C.G., D.H. Abbott \& J.U.M. Jarvis. 1990. Social suppression of ovarian cyclicity in captive and wild colonies of naked mole-rats, Heterocephalus glaber. J. Reprod. Fertil. 88: 559-568.

Feder, H.H., J.A. Resko \& R.W. Goy. 1968. Progesterone concentrations in the arterial plasma of guinea-pigs during the oestrous cycle. J. Endocrinol. 40: 505-513.

Fickel, J., A. Wagcher \& A. Ludwig. 2007. Semen cryopreservation and the conservation of endangered species. Eur. J. Wildlife. Res. 53: 81-89.

Guimarães, D.A. 1993. Algumas características reprodutivas da cutia fêmea Dasyprocta prymnolopha (Wagler, 1831) criada em cativeiro. MSc Thesis, Federal University of Pará, Belém, Brazil.

Guimarães, D.A. 2000. Aspectos reprodutivos e endócrinos da puberdade, ciclo estral, gestação e cio pós-parto de cutias (Rodentia: Dasyproctidae), criadas em cativeiro. Ph.D. Thesis, Federal University of Pará, Belém, Brazil.

Guimarães, D.A., R.S.L. Ramos, G.W. Garcia \& O.M. Ohashi. 2009. The stimulatory effect of male agouti (Dasyprocta prymnolopha) on the onset of female puberty. Acta Amazon. 39: 759-762.

Heap, R.B., D.N. Ackland \& B.J. Weir. 1981. Progesterone-binding proteins in plasma of guinea pigs and other hystricomorph rodents. J. Reprod. Fertil. 63: 477-489.

Miglino, M.A., A.L. Franciolli, M.F. de Oliveira, C.E. Ambrósio, M. Bonatelli, M.R. Machado \& A. Mess. 2008. Development of the inverted visceral yolk sac in three species of caviids (Rodentia, Caviomorpha, Caviidae). Placenta 29: 748-52. 
Miglino, M.A., A.M. Carter, C.E. Ambrosio, M. Bonatelli, M.F. de Oliveira, R.H. dos Santos Ferraz, R.F. Rodrigues \& T.C. Santos. 2004. Vascular organization of the hystricomorph placenta: a comparative study in the agouti, capybara, guinea pig, paca and rock cavy. Placenta 25: 438-48.

Miglino, M.A., A.M. Carter, R.H. dos Santos Ferraz \& M.R. Fernandes Machado. 2002. Placentation in the capybara (Hydrochaerus hydrochaeris), Agouti (Dasyprocta aguti) and paca (Agouti paca). Placenta 23: 416-28.

Montes, R.C. \& E.A.C. Baz. 2006. Actividad ovárica del tepezcuintle Agouti paca (Rodentia: Agoutidae) en cautiverio. Rev. Biol. Trop. 54: 903-912.

National Research Council. 1991. Microlivestock: little known animals with a promising economic future. National Academy, Washington D.C., USA.

Rodrigues R.F., A.M. Carter, C.E. Ambrosio, T.C. dos Santos \& M.A. Miglino. 2006. The subplacenta of the red-rumped agouti (Dasyprocta leporina L). Reprod. Biol. Endocrinol. 4: 31
Rowlands, I.W., W.H. Tam \& D.G. Kleiman. 1970. Histological and biochemical studies on the ovary and of progesterone levels in the systemic blood of the green acouchi (Myoprocta pratti). J. Reprod. Fertil. 22: $533-545$

Tam, W.H. 1973. Progesterone levels during the oestrous cycle and pregnancy in the cuis Galea musteloides. J. Reprod. Fertil. 35: 105-114.

Van Aarde, R.J. 1985. Circulating progesterone and oestradiol-17ß concentrations in cyclic cape porcupines, Hystrix africaeaustralis. J. Reprod. Fertil. 75: 583-591.

Wildt, D.E. \& C. Wemmer. 1999. Sex and wildlife: the role of reproductive science in conservation. Biodivers. Conserv. 8: 965-976.

Weir, B.J. 1971. Some observations on reproduction in the female agouti, Dasyprocta agouti. J. Reprod. Fertil. 24: 203-211.

Weir, B.J. 1974. Reproductive characteristics of hystricomorph rodents. Symp. Zool. Soc. Lond. 34: 265-301. 